DOI 10.22363/2618-897X-2019-16-1-45-51

\title{
Translingualism / Transculturality and Ethno-Cultural Identity: Complementarity or Conflictness?
}

\author{
G.T. Khukhuni, I.I. Valuitseva \\ Moscow State Region University \\ Vera Voloshina str., Bld. 24, Mytishchi, 141014, Moscow Region, Russian Federation
}

\begin{abstract}
The article deals with a few aspects of translingualism and their influence on ethno-cultural and ethno-lingual consciousness. The authors postulate that a statement of the harmonic coexistence between the 'native' and the 'acquired', with all its attractiveness and 'magnetism', isfar from being always proven in practice. In addition, the 'smoothness' of transition from one linguistic culture to another and the 'cross-flow' of languages and cultures into each other can be perceived as a threat to the preservation of the 'native' linguocultural identity and an implicit form of the 'linguistic imperialism'. In this regard, it seems appropriate to objectively analyze the phenomena of translingualism and transculturalism and to consider the associated positive and negative consequences in more details.
\end{abstract}

Key words: translingualism, transculturalism, ethno-lingual, ethno-cultural, language, consciousness

\section{Introduction}

A range of problems associated with the study of the interaction of languages has a long tradition going back essentially to the theories of the 'mixture of languages' (H. Scuchardt, J. Baudouin de Courtenay, etc.) in the last third of the 19th century. After the formation of sociolinguistics as an independent scientific discipline, the said problem was discussed in U. Weinreich's monography of 1953 (its Russian translation was published in 1979 [1]) and other studies dedicated to the problem of bilingualism.

On the other hand, the generally accepted thesis that the interaction of languages is always to some extent the interaction of cultures (the sources of which to a certain extent can be found in the scientific school of Wörter und Sachen, again leading us to the heritage of G. Schuchardt [2] and his followers, although they dealt with this issue in a purely historical-linguistic sense), contributed to linking these problems with the development of various aspects of intercultural communication, in particular, the concept of biculturalism. This thesis stimulated the study of bilingualism in connection with different aspects of international communication, including the notion of biculturalism.

In recent decades, there has been a definite shift towards another conceptual pair of terms: translingualism (translinguality) and transculturalism (transculturality). A profound study of the said phenomena, including the connection of the said terms with other units of this terminological system, may be found in works by Z. Proshina [3; 4], U. Bakhtikireeva $[5 ; 6]$ and others $[7 ; 8]$. It gives us a possibility to discuss some controversial points of translingualism and transculturality without a detailed review of their understanding in the past and at present. 


\section{Discussion}

As the very name of the Third International Conference held in 2017 under the aegis of the International Association of the Russian Language and Literature Teachers (MAPRYAL) shows: "Bilingualism and Translingualism: pros\&cons", its organizers have fully realized that when assessing certain points related to these phenomena, a mismatch of views is assumed. However, when looking through most of the studies devoted to this issue, one can see that "an upbeat outlook" prevails in them, such as the overcoming of ethno-cultural narrowness, entering "the foreign world" while maintaining the "inheritance" of one's own culture, the enrichment of idioms in the process of "translingualization" (we use this term in the absence of a more appropriate one), etc. Without doubting the availability of all of the above findings, which, at first glance, seem to be extremely positive, we will try to speak on some of them in the role of the advocates diaboli.

Linguistic Impacts of Translingualism. According to most authors (see e.g. the article by Z. Proshina with the detailed analysis of the relevant researches), translingualism may be defined as a smooth transition from one linguoculture to another and their certain merging without a full assimilation but with the maintenance of linguocultural identity of language users resulting in the mixed discourse. Translingualism means the penetrability of languages, their interaction providing with a new quality of the enriched linguoculture. The sphere of translinguality may be characterized as the blur or 'linguistic fluidity' [3. P. 160].

We think that this definition requires some clarification. First, the declared 'smoothness' is possible (although it is rather relative) on an individual level, but it seems questionable in respect of language communities. As has been repeatedly proven in history, including the recent one, even the "smoothest" entrance of representatives of a given ethnos in another (foreign) language (not just its good knowledge and fluent using, but namely its recognition as their own language), especially on a large scale basis, may provoke a negative reaction. In the 1970s - early 1980s, the Soviet Union sanctioned and propagated the thesis about "a new historical community of people - the Soviet folk", and that Russian was chosen as "the second native language" for this community (naturally, on a "voluntary" basis). It must be added, however, that neither the existence of the first native language, nor the necessity of its cultivation were officially ignored. Nevertheless, the two questions could be heard in many of the Soviet Republics (initially, in private 'kitchen talks' and later, during the perestroika years, - publicly):

a) Can a normal person have two mothers'voluntarily', and

b) What "the second native language" must have the people for whom the first one is Russian? We will not touch upon a question of how much political demagogy was in such statements, but the role that those sentiments played in the further destiny of the country, unfortunately, is well known to all of us. These views may be labelled as "backwardness" and an archaic worldview; but the possibility of such a reaction must be taken into account.

Something similar is observed now in respect of the English language. This fact is mainly provoked by 'globalistic' declarations on the necessity to introduce English in socially important spheres (science, economics, education, etc.) in all countries as the only way to meet challenges of modern times. Sometimes, they lead to the exhortations 
about the necessity 'to bring up new Nabokovs in the era of total multilingualism with the obligatory English repertoire' (taken from [9. P. 151]). However, a clear and cogent answer for the questioning of which second language must (namely, must and not may) have people who live in English-speaking countries and whose first language is English seems hardly possible. Such a situation often gives rise to the suspicion that the "overflowing" is an euphemism for "absorbing" one's own language, at the best case scenario - turning it into a kind of a substrate "dissolved" in the global language — that is, essentially, the same language imperialism in a new appearance.

Secondly, the statement about "some merging" of interacting linguistic cultures also seems to be not quite definite. From purely linguistic point of view, the term 'merging' seems inappropriate because it is usually understood in sociolinguistics as the appearance of a hybrid idiom (pidgin or creole) that cannot be identified with any of the contacting languages . It is clear that 'translingual' literary creations are not connected either with creoles or with pidgins. This aspect must be regarded because (as Prof. Z. Proshina notes) a tendency to differentiate the notions of bilingualism and translingualism according to their use in belles-lettres can be sometimes observed. Namely, bilingualism is understood as the ordinaryknowledge of two languages and their use in communication, whereas the second term implies an ability to create masterpieces in more than one language. In this dichotomy, traditional bilingualism is usually defined as 'ordinary'or 'everyday' one [9. P. 151].

It seems that such interpretation isn't quite correct: a person may write fiction in two languages but it doesn't necessary mean that he/she creates a masterpiece. We may add that I. Turgenev whose bilingualism was not limited to an 'everyday level' denied the ability to create 'translingual' masterpieces [10] (although he, of course, didn't know the term 'translingualism').

Thirdly, as it has been mentioned above, the area of translinguality characterized with 'blurriness and fluidity' is often interpreted as a possibility for the translingual persons to successfully use languages from their bilingual repertoire, violating sometimes the norms and adapting linguistic codes for their purposes and specific contexts' [4. P. 6]. However, such aspect may be assessed not only as the 'enrichment of the linguoculture', but also as a process leading to its degradation. In other words, it means the destruction of linguistic norms as a result of the interference. First, we mean herein a language norm in its proper linguistic sense. Russian linguist A. Peshkovsky wrote in the 1920s, the period when the existing norm was also under the threat of disintegration, that a teacher in school defends the spiritual integrity of the nation by preserving the norm of the language in the way a solder defends its territorial integrity. And such defense, according to the author, is more important than military one because the territorial disintegration doesn't exclude a possibility of the future restoration but the spiritual disintegration remains forever [13. P. 24].

The described process may also lead to the serious distortion of the linguistic identity and the vanishing of some basic characteristics of the language personality [14. P. 172]. This fact may have quite negative consequences.

All the above does not in any way mean a denial of enormous contribution to the global and regional cultures that bi- / translingual writers have made and are making. However, 
as Prof. U. Bakhtikireeva postulates, - a creative person who transmits his national picture of the world by means of another language has to pay a high price for the familiarizing of a Russian (respectively, and any other "not his own" language speaker G. Kh., I.V.) native speaker with the worldview of his/her folk. She underlines that a bilingual writer feels himself in the situation of the 'insanity converted into home', because the dialogue between two entities takes place in his mind [15]. It is clear that such process provokes contradictions, sometimes very serious ones.

Transculturality and Ethno-Cultural Identity. Let us turn again to the work of Prof. Z. Proshina where she underlines that transculturalism/transculturality presupposes the simultaneous coexistence in different cultures with the preservation of imprints of the both. The result of transculturality is a gradual change of the culture, including its hybridization [4. P. 6]. This notion is closely related to the phenomenon of translinguality, but they must not be identified because the relation between a language and a culture is more complicated.

Such marginal position actually enables to comprehend the sides of reality that are inaccessible for not-translingual persons. At the same time, the word marginality has also some negative connotations. In other words, the situation, when an individual plays a role of a few identities in both cultures [4. P. 6], may raise a question of his actual ethnocultural identification. In such occasion, the transcultural person finds himself in the situation of 'neither here nor there', i.e. he is not fully accepted by 'normal' representatives of either of the cultures, especially under a situation of the conflict existing between them.

Finally, speaking of transculturality, one should not forget about such element of interacting cultures as their religious component. When it comes to world religions (Christianity, Islam, Buddhism), it is not ethnic in the proper sense of the word; but it is hardly advisable to neglect it as one of the factors shaping the national-cultural specifics of the linguistic personality. The latter may not belong to the respective confession; but aspects of the cultural background associated with it are usually manifested to a certain degree, perhaps at an unconscious level. In those cases where coexistence occurs in cultures belonging to different religious traditions, it is probable that the above-mentioned hybridization may face additional difficulties.

\section{Conclusions}

Summing up this article, we may conclude the following. Translingualism and transculturality are objective facts of the modern reality. The process of globalization will undoubtedly inspire the expansion of the scope of their functioning. On the other hand, a number of issues associated with them (a social position of its representatives in interacting ethno-cultural groups, the influence of transcultural texts on the language norm, features of the translingual language personality and its ethno-cultural identity, etc.) demand the further research.

\section{References}

1. Weinreich, U. 1979. Yazykovye kontakty. Sostoyanie i problem issledovaniya [Languages in Contact. Findings and Problems]. Kiev: Vishcha shkola. 264 p. Print. (In Russ.) 
2. Shuchardt, G. 1950. Izbrannye stat'i po yazykoznaniyu [Selected Articles on Linguistics]. Moscow: Izdatel'stvo inostrannoj literatury. Print. (In Russ.)

3. Proshina, Z.G. 2017. "Translingvizm i ego prikladnoe znachenie" [Translingualism and its Application]. Vestnik RUDN. Seriya: Voprosy obrazovaniya, yazyki i special'nost'. 14 (2): 155 170. Print. (In Russ.)

4. Proshina, Z.G. 2016. "Problemy perspektivy translingval'nyh i transkul'turnyh kontaktov (vvedenie k tematicheskomu vypusku zhurnala)" [The Problems and Perspectives of the Translingual and Transcultural Contacts. An Introduction to the Thematic Issue of the Journal]. Social'nye i gumanitarnye nauki na Dal'nemVostoke. 2 (50): 6-9. Print. (In Russ.)

5. Bahtikireeva, U.M. 2016 "O translingvizme i trankul'turacii cherez prizmu odno jyazykovoj biografii" [About the Translingualism and Tranculturation through a Prism of the One Language Biography]. Social'nye i gumanitarnye nauki na Dal'nemVostoke. 2 (50): 76-80. Print. (In Russ.)

6. Bahtikireeva, U.M., and O.A. Valikova. 2017 "Translingvizm i revitalizaciya kul'tury" [Translingualism and the Revitalization of Culture]. Vestnik RUDN. Seriya: Teoriya yazyka, semiotika. Semantika. 8 (1): 57-63. Print. (In Russ.)

7. Meillet, A. 1954. Sravnitel'nyj metod v istoricheskom yazykoznanii [Comparative Method in Historical Linguistics]. Moscow: Izdatel'stvo inostrannoj literatury. Print. (In Russ.)

8. Starostin, G.S. et. al. 2016. K istokam yazykovogo raznoobraziya. Desyat' besed o sravnitel'noistoricheskom yazykoznanii s G.Ya. Satanovskim [To the Origins of the Diversity of the Languages. Ten Interviews about Comparative Linguistics with G. Satanovsky]. Moscow: Izdatel'skijdom «Delo» RAHiGS. Print. (In Russ.)

9. Kakrakuc-Borodina, L.A. 2007. "Translingvizm i yazykovaya igra (na material proizvedenij V.V. Nabokova)" [Translingualism and the Word Play (on the Material of V. Nabokov's Works]. Vestnik Sankt-Peterburgskogo universiteta. Seriya 9. 3: 151-154. Print. (In Russ.)

10. Turgenev, I.S. Pis'mo v redakciyu «Nashego veka» [A Letter to the Editorial Board of "Nash Vek"]. Web. URL: http://gumfak.ru/otech_html/turgenev/kritika/062-25.html (accessed: 26.07.2018).

11. Hrolenko, A.T. Teoriya yazyka: uchebnoe posobie [Language Theory. A Manual]. Web. URL: https://librolife.ru/g4302018 (accessed: 26.07.2018).

12. Gamzatov, R. Jazyk (iz knigi «Moj Dagestan») [Language (from the Book "My Dagestan”)]. Web. URL: http://rus.1september.ru/article.php?ID=200304702. (accessed: 16.08.2018).

13. Peshkovskij, A. M. Ob" ektivnaya i normativnaya tochka zreniya na yazyk [An Objective and Normative Viewpoint on Language]. Web. URL: https://studfiles.net/preview/4343134/ (accessed: 27.07.2018).

14. Bubnova, I.A., Zykova N.V., Krasnyh V.V., and N.V. Ufimceva. 2017. (Neo)psiholingvistika i (psiho)lingvokul'turologiya: novye nauki o cheloveke govoryashchem [(Neo)psycholinguistics and (Neo)linguoculturology: New Sciences about Homo Loquens]. Moscow: Gnozis. Print. (In Russ.)

15. Bahtikireeva, U.M. 2009. "Transfer” [Transfer]. Druzhba narodov 12. Web. URL: http:// magazines.russ.ru/druzhba/2009/12/ba12.html (accessed: 26.07.2018).

16. Epstein, M. Novyj vid svobody - transkul'tura [New Kind of Freedom - Transculture]. Web. URL: http://www.topos.ru/veer/59/epst_tra.html. (accessed: 26.07.2018).

17. Tlostanova, M.V. 2008. Ot filosofii mul'tikul'turalizma k filosofii transkul'turacii [From the Philosophy of Multiculturalism to the Philosophy of Transculturality]. Moscow: RUDN. Print. (In Russ.)

18. Rubins, M. Literatura $\mathrm{v}$ kontekste transnacional'noj teorii [Literature in the Context of Transnational Theory]. Web. URL: http://lib.knigi-X.ru/23istoriya/89357-1-literatura-kontekstetransnacionalnoy-teorii-rubins-londonskiy-universitet-velikobritaniya-literature-the-context. php. (accessed: 16.08.2018).

(C) Khukhuni G.T., Valuitseva I.I., 2018

This work is licensed under a Creative Commons Attribution 4.0 International License 
Article history:

Received: 02.09.2018

Accepted: 09.12.2018

Moderator: U.M. Bakhtikireeva

Conflict of interests: none

For citation:

Khukhuni, G.T., and I.I. Valuitseva. 2019. "Translingualism / Transculturality and Ethno-Cultural Identity: Complementarity or Conflictness?”. Polylinguality and Transcultural Practices, 16 (1), 45-51. DOI 10.22363/2618-897X-2019-16-1-45-51

\title{
Remark:
}

The text of the article was submitted as a report on IV International Conference "Bi-, Poly-, Translingualism and Language Education”, Moscow, December 7-8, 2018.

\section{Bio Notes:}

Georgiy T. Khukhuni is a Doctor in Philology, Professor, Head of the Department of Theory of Language and English, Moscow State Regional University. E-mail: khukhuni@mail.ru

Irina I. Valuitseva is a Doctor in Philology, Professor, Professor of the Department of Theoretical and Applied Linguistics, Moscow State Regional University. E-mail: irinaiv-v@yandex.ru

\section{Транслингвизм, транскультуральность и этнокультурная идентичность: комплементарность или конфликтность?}

\author{
Г.Т. Хухуни, И.И. Валуйцева \\ Московский государственный областной университет \\ Российская Федерация, Московская область, 141014, Мытищи, ул. Веры Волошиной, д. 24
}

Статья посвящена некоторым аспектам транслингвизма и его влиянию на этнокультурное и этноязыковое сознание. Отмечается, что тезис о гармоничном сосуществовании «исконного» и «приобретенного», при всей его привлекательности, далеко не всегда находит подтверждение на практике, а «плавность» перехода от одной лингвокультуры к другой и «взаимное перетекание» языков и культур друг в друга могут восприниматься как угроза сохранению «исконной» лингвокультурной идентичности и завуалированная форма языкового империализма. В связи с этим представляется целесообразным объективный анализ феноменов транслингвизма и транскультуральности и более тщательное рассмотрение связанных с ними позитивных и негативных последствий.

Ключевые слова: транслингвизм, транскультуральность, этноязыковой, этнокультурный, язык, сознание

\section{История статьи:}

Дата поступления в редакцию: 02.09.2018

Дата принятия к печати: 09.12.2018

Модератор: У.М. Бахтикиреева 
Конфликт интересов: отсутствует

\section{Для цитирования:}

Хухуни Г.Т., Валуйцева И.И. Транслингвизм, транскультуральность и этнокультурная идентичность: комплементарность или конфликтность? // Полилингвиальность и транскультурные практики. 2019. Т. 16. № 1. C. 45-51. DOI 10.22363/2618-897X-2019-16-1-45-51

\section{Примечание:}

Статья была представлена в качестве доклада на IV Международной конференции под эгидой МАПРЯЛ «Би-, поли-, транслингвизм и языковое образование», Москва, 7-8 декабря 2018.

\section{Сведения об авторах:}

Хухуни Георгий Теймуразович - доктор филологических наук, профессор, заведующий кафедрой теории языка и англистики Московского государственного областного университета. E-mail: khukhuni@mail.ru

Валуйцева Ирина Ивановна - доктор филологических наук, профессор, профессор кафедры теоретической и прикладной лингвистики Московского государственного областного университета. E-mail: irinaiv-v@yandex.ru 